\title{
Studi Deskriptif Spiritual Well Being Warga Binaan Pemasyarakatan Laki-laki berdasarkan Usia di Lembaga Pemasyarakatan Kantor Wilayah Kementerian Hukum dan Hak Asasi Manusia Jawa Tengah: Studi Pendahuluan
}

\author{
Dwi Fijianto' ${ }^{1}$, Megah Andriany ${ }^{2}$, Elis Hartati ${ }^{3}$
}

1. Departemen Ilmu Keperawatan Fakultas Kedokteran Universitas Diponegoro, email: viaradwi@gmail.com

2. Departemen Ilmu Keperawatan Fakultas Kedokteran Universitas Diponegoro

3. Departemen Ilmu Keperawatan Fakultas Kedokteran Universitas Diponegoro

\begin{abstract}
Abstrak. Lembaga Pemasyarakatan Laki-laki di Indonesia mengalami kelebihan daya tampung Warga Binaan Pemasyarakatan (WBP). Kondisi ini mengakibatkan terjadinya masalah psikososial yang berdampak terhadap spiritual well being WBP laki-laki. Penelitian sebelumnya menjelaskan beberapa faktor yang dapat mempengaruhi spiritual well being, namun subjek pada penelitian sebelumnya bukan WBP laki-laki yang mengalami masalah psikososial dan tidak berfokus pada salah satu faktor yaitu usia. Penelitian ini bertujuan untuk mengetahui tingkat spiritual well being WBP laki-laki berdasarkan usia WBP. Jenis penelitian kuantitatif, dilakukan studi observasional dengan metode penelitian cross sectional. Teknik pengambilan sampel menggunakan non probability sampling dengan metode purposive sampling. Analisis data yang dilakukan adalah analisis univariat untuk mengetahui presentase usia dan spiritual well being WBP laki-laki. Jumlah sampel sebanyak 115 responden WBP laki-laki dengan kriteria inklusi WBP laki-laki berusia 17-55 tahun, WBP laki-laki yang bisa membaca, WBP laki-laki yang kooperatif, dan WBP laki-laki yang beragama Islam. Instrumen pengambilan data menggunakan Spiritual Well Being Scale (SWBS) Ellison. Hasil penelitian menunjukkan spiritual well being WBP laki-laki meningkat ketika usia dewasa akhir dan lansia awal. Simpulan penelitian ini adalah dengan bertambahnya usia, spiritual well being WBP laki-laki mengalami peningkatan.
\end{abstract}

Kata kunci: spiritual well being, usia WBP laki-laki.

\section{Descriptive Study Spiritual Well Being of Male Inmates Guidance by Age at the Correctional Institution of the Ministry's Regional Office Law and Human Rights in Central Java: Preliminary Studies}

\begin{abstract}
Male Correctional Institutions in Indonesia experience an over capacity for inmates. The condition causes psychosocial problems that affect the spiritual well being of male inmates. Previous research explained about several factors influencing spiritual well being, but the subject was not male inmates who experience psychosocial problems and did not focus on age. This study aims to determine the level of spiritual well being of male inmates based on the age of inmates. This type of quantitative research, an observational study with cross sectional research methods. The sampling technique uses non probability sampling with a purposive sampling method. Data analysis was performed by univariate analysis to determine the percentage of age and spiritual well being of male inmates. The total sample of 115 respondents were male inmates with inclusion criteria of male inmates aged 17-55 years, male inmates who could read, male inmates who were cooperative, and male inmates who were Muslim. The data collection instrument used Ellison's Spiritual Well Being Scale (SWBS). The results showed the spiritual well being of male inmates increases when late adulthood and early elderly. The conclusion of this study is that with increasing age, the spiritual well being of male inmates has increases.
\end{abstract}

Keywords: age of male inmates, spiritual well being, 


\section{Pendahuluan}

Angka

W arga

Binaan

pemasyarakatan (WBP) laki-laki di indonesia mengalami peningkatan setiap tahun. Urutan angka terbesar WBP lakilaki pada tahun 2018 terdapat pada Kantor Wilayah (Kanwil) Kementerian Hukum dan Hak Asasi Manusia (Kemenkumham) Sumatera Utara, Jawa Timur, Jawa Barat, Daerah Khusus Ibukota Jakarta dan Kanwil Jawa Tengah. WBP laki-laki pada setiap Kanwil melebihi daya tampung dari Lembaga Pemasyarakatan (Lapas) yang ada (Direktorat Pembinaan dan latihan Kerja Narapidana, 2018)

Kondisi Lapas yang melebihi daya tampung menyebabkan masalah psikososial pada WBP laki-laki (Listwan dkk, 2012). Hatala, 2013 menjelaskan masalah psikososial WBP laki-laki yang dialami di Lapas berpengaruh terhadap spiritual well being WBP laki-laki. Spiritual well being (kesejahteraan spiritual) adalah ekspresi hubungan antara manusia dengan Tuhan dengan menunjukkan adanya kepuasan hidup (Ellison, 1983 \& Eksi H dkk, 2017).

Fisher (2009) menjelaskan Spiritual well being pada WBP laki-laki dipengaruhi beberapa faktor, salah satunya adalah tahap perkembangan/usia, Tahap perkembangan/usia WBP laki-laki akan mempengaruhi pandangan dan persepsi terhadap Tuhan, bentuk serta cara mendekatkan diri kepada Tuhan. Usia perkembangan WBP laki-laki dengan agama yang berbeda memiliki pandangan yang sama tentang Tuhan, namun memiliki perbedaan dalam bentuk sembahyang untuk mendekatkan diri kepada Tuhan sesuai seks, agama dan kepribadian.

Penelitian Fisher (2009) menjelaskan adanya beberapa faktor yang dapat mempengaruhi spiritual well being di antaranya keluarga, pengalaman hidup masa lalu, etnik dan budaya, kedalaman spiritual, keyakinan dan isu moral terkait dengan keadaan, dan usia/tahap perkembangan. Subjek penelitian adalah masyarakat umum bukan WBP laki-laki yang mengalami masalah psikososial. Penelitian tidak berfokus pada salah satu faktor yang dapat mempengaruhi spiritual well being.

Bini'matilah (2018) dan Fisher (2011) mengungkapkan bahwa spiritual well being menjadi sumber kekuatan bagi manusia yang tahap perkembangan usia lanjut dalam menghadapi masalah dan meningkatkan kualitas hidup. Penelitian membahas hubungan antara kesejahteraan spiritual yang dialami lanjut usia terhadap kesehatan.

Penelitian ini berbeda dengan penelitian sebelumnya. Subjek dalam penelitian ini adalah WBP laki-laki yang mengalami masalah psikososial. Penelitian ini untuk mengetahui tingkat spiritual well being WBP laki-laki berdasarkan usia WBP, sehingga perawat dapat berperan dalam memberikan kebutuhan spiritual WBP laki-laki sesuai dengan usia perkembangannya.

\section{Metode}

Desain penelitian merupakan penelitian kuantitatif dengan studi observasional menggunakan metode penelitian potong lintang (cross sectional) (Nursalam, 2013). Populasi dalam penelitian ini adalah WBP laki-laki di dua Lembaga Pemasyarakatan pada Kantor Wilayah Kemenkumham Jawa Tengah. Penelitian dilaksanakan pada bulan Agustus-September 2019. Teknik pengambilan sampel penelitian ini adalah teknik non probability sampling dengan metode purposive sampling (Sugiyono, 2016).

Sampel penelitian yang diambil sesuai dengan tujuan peneliti dengan kriteria inklusi antara lain WBP laki-laki berusia 17-55 tahun, WBP laki-laki yang bisa membaca, WBP laki-laki yang kooperatif, dan WBP laki-laki yang beragama Islam. WBP laki-laki yang sesuai dengan kriteria inklusi yang ditentukan oleh peneliti diambil sebagai sampel penelitian 
(Nursalam, 2016). Sampel penelitian berjumlah 115 responden.

Pengambilan data dilakukan dengan cara WBP laki-laki mengisi kuesioner spiritual well being scale (SWBS) setelah mengisi form informed concent. SWBS adalah alat ukur untuk mengetahui tingkat spiritual well being. Kuesioner SWBS merupakan kuesioner yang valid dengan nilai validitas cronbach alpha $>0,8$ dan nilai reliabilitas cronbach alpha $=0,895$ (Utama, 2015).

Analisis data dalam penelitian ini adalah analisis univariat. Analisis yang dilakukan bertujuan untuk mendapatkan gambaran statistik deskriptif usia responden dan hasil pengukuran spiritual well being WBP laki-laki. Penyajian data menggunakan tabel distribusi frekuensi berupa jumlah dan persentase data.

\section{Hasil Penelitian}

Hasil penelitian merupakan data deskriptif berupa karakteristik responden yang meliputi usia dan data spiritual well being WBP laki-laki. Penyajian data selanjutnya adalah analisis univariat berupa presentase data spiritual well being berdasarkan usia WBP laki-laki.

1. Karakteristik Responden

a. Distribusi Karakteristik Responden Berdasarkan Usia.

Tabel 1.1 Distribusi responden berdasarkan usia menurut Departemen Kesehatan RI Tahun 2009 (n:115).

\begin{tabular}{|c|c|c|c|c|}
\hline No & $\begin{array}{c}\text { Karakteristik } \\
\text { Responden }\end{array}$ & Kategori Usia Responden & Jumlah & $(\%)$ \\
\hline \multirow[t]{4}{*}{1} & Usia & Remaja Akhir (17-25 tahun) & 26 & $22.61 \%$ \\
\hline & & Dewasa Awal (26-35 tahun) & 36 & $31.30 \%$ \\
\hline & & Dewasa Akhir (36-45 tahun) & 32 & $27.83 \%$ \\
\hline & & Lansia Awal (46-55 tahun) & 21 & $18.26 \%$ \\
\hline & & h Total & 115 & $100 \%$ \\
\hline
\end{tabular}

Berdasarkan tabel di atas menunjukkan sebagian besar usia responden berada pada usia dewasa awal (26-35 tahun) yaitu sebanyak $31,30 \%$. Selanjutnya usia dewasa akhir (36-45 tahun) sebanyak $27,83 \%$, dan usia remaja akhir (17-25 tahun) sebanyak $22,61 \%$. Usia responden dengan jumlah paling sedikit pada usia lansia awal (46-55 tahun) sebanyak 18,26\%.

2. Analisis Univariat

a. Tabel berikut menggambarkan data dari variabel spiritual well being berdasarkan usia

Tabel 2.1 Hasil Pengukuran Spiritual Well Being (SWB)berdasarkan Usia

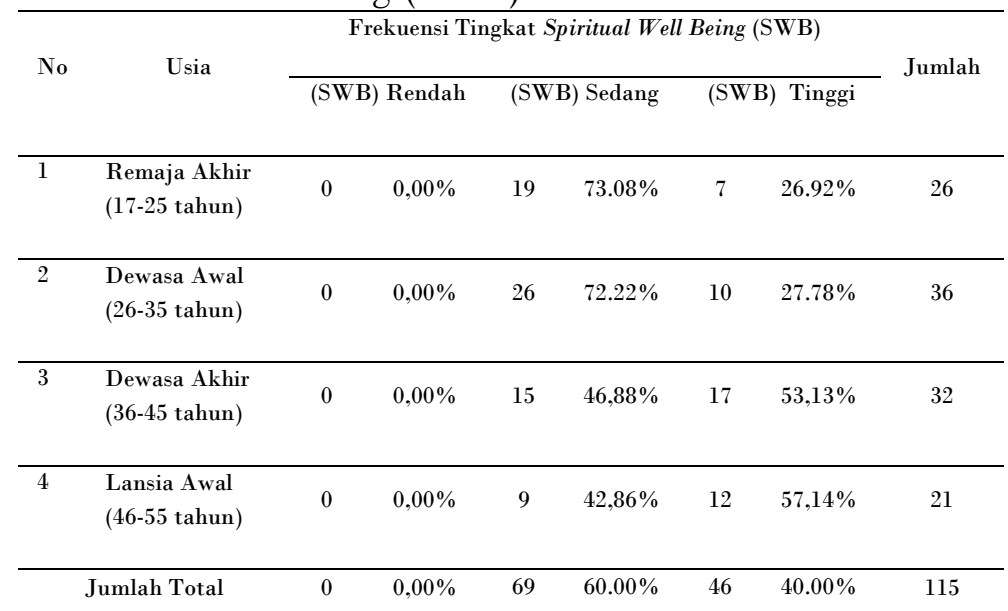

Berdasarkan tabel 2.1 menunjukkan sebagian besar WBP laki-laki memiliki spiritual well being sedang sebanyak $60 \%$. Tingkat spiritual well being pada kelompok usia menunjukkan presentase spiritual well being tinggi terbesar pada kelompok usia lansia awal (46-55 tahun) sebanyak 57, 14\% diikuti kelompok usia dewasa akhir (36-45 tahun) sebanyak 53,13\%. Sedangkan presentase spiritual well being sedang terbesar pada kelompok usia remaja akhir (17-25 tahun) sebanyak $73,08 \%$ diikuti kelompok usia dewasa awal (26-35 tahun) sebanyak $72,22 \%$.

Berdasarkan tabel 2.1 menunjukkan adanya perbedaan presentase spiritual well being pada setiap kelompok usia WBP lakilaki. Perbedaan presentase spiritual well being menunjukkan tingkat spiritual well being WBP laki-laki cenderung meningkat sejalan dengan bertambahnya usia WBP laki-laki. 


\section{Pembahasan}

Berdasarkan hasil penelitian, menunjukkan terdapat perbedaan presentase tingkat spiritual well being WBP laki-laki. Dimana semakin bertambah usia WBP laki-laki maka tingkat spiritual well being semakin meningkat, hal tersebut seperti ditunjukkan pada tabel 2.1. Hasil ini sejalan dengan penelitian yang dilakukan oleh Fisher (2009) yang menyatakan bahwa spiritual well being diantaranya dipengaruhi oleh usia perkembangan. Semakin bertambahnya usia akan mempengaruhi persepsi dan pandangan terhadap Tuhan dan akan berpengaruh pada tujuan hidup manusia. Hasil tersebut juga sejalan dengan penelitian Bini'matilah (2018) yang mengungkapkan spiritual well being menjadi sumber kekuatan bagi manusia yang tahap perkembangan usia lanjut dalam menghadapi masalah dan meningkatkan kualitas hidup. Penelitian lain juga menyebutkan bahwa sebagian besar seseorang dengan usia yang lebih tua memiliki tingkat spiritual well being tinggi (Purborini, 2009). Penelitian Paloutzian (2012) menyebutkan bahwa pada usia remaja tingkat spiritual well being tidak lebih baik daripada usia yang berada di atasnya.

Penelitian menunjukkan peningkatan spiritual well being pada kelompok usia. Semakin meningkat usia WBP laki-laki maka spiritual well being juga semakin meningkat. Hal ini dapat terjadi karena pada masa usia matang (dewasa akhirlansia awal) WBP laki-laki akan kembali pada fitrah dan spiritualitas dalam hidupnya. Fitrah dan spiritualitas ini mengarah pada ketaatan terhadap Tuhan dan tujuan hidup (Jalaluddin, 2015). Sedangkan pada usia remaja akhir dan dewasa awal WBP laki-laki berada pada masa mengalami konflik internal dalam diri untuk menentukan kepribadian dan perkembangan diri. Pada masa ini WBP laki-laki lebih berfokus bagaimana untuk mencapai hubungan sosial dan mengekspresikan diri (Jalaluddin, 2015 \& Herlina, 2013).

Penelitian ini memiliki kelemahan dalam pelaksanaannya, diantaranya karakteristik faktor yang memepengaruhi spiritual well being WBP laki-laki yang diteliti terbatas pada usia WBP laki-laki, dan pengambilan data dilakukan sekali, sehingga tidak dapat menilai perubahan tingkat spiritual well being WBP laki-laki.

\section{Simpulan}

Berdasarkan hasil penelitian dapat disimpulkan bahwa tingkat spiritual well being WBP laki-laki mengalami peningkatan seiring dengan bertambahnya usia.

Saran peneliti berdasarkan hasil penelitian adalah perawat hendaknya dapat memberikan terapi/program kegiatan spiritual bagi WBP laki-laki untuk meningkatkan spiritual well being WBP lakilaki, seheingga dapat mencapai tujuan dan kepuasan hidup.

\section{Daftar Pustaka}

Bini'matillah U. Hubungan spiritualitas dengan kesepian pada lansia di UPT Pelayanan Sosial Tresna Werdha (PSTW) Jember. Digit Repos Univ Jember 2018.

Departemen Kesehatan Republik Indonesia. Kategori Umur Manusia. 2009.

Direktorat Pembinaan dan latihan Kerja Narapidana. Sistem database pemasyarakatan, kanwil \& ditjenpas. 2018.

Eksi H \& Kardas S. Spiritual Well-Being: Scale Development and Validation*. Spirituaal Psychol Couns 2017;2(1):73-88.

Ellison CW. Spiritual well being: Conceptualization and measurement. J Psychol Theol 1983;11(4):330-8.

Fisher JW. Reaching the heart: Assesing and nurturing spiritual well being. Disertation. Aust Univ Drive, Mt Helen Ballarat 2009. 
Fisher JW. The four domains model: connecting spirituality, health and well-being. Religions. 2011; 2:17-28

Hatala AR. Towards a biopsychosocial - spiritual approach in health psychology: Exploring theoretical orientations and future directions. J Spiritual Ment Heal 2013;(October):37-41.

Herlina (2013), Bibliotherapy: Mengatasi masalah anak dan remaja melalui buku, Pustaka Cendekia Utama, Bandung.

Jalaluddin. Tingkat usia dan perkembangan spiritualitas serta faktor yang melatarbelakanginya di Majelis Tamasya Rohani Riyadhul Jannah Palembang. Intizar 2015; 21:2;165-183.

Listwan SJ, Hanley D, Colvin M. The prison experience and reentry: Examining the impact of victimization on coming home final report. US Dep Justice 2012.

Nursalam (2013), Metodologi penelitian ilmu keperawatan, pendekatan praktis, Salemba Medika, Jakarta.

Nursalam (2016), Metodologi Penelitian Ilmu Keperawatan. Salemba medika, Jakarta.

Paloutzian RF, Bufford RK, Wildman AJ. Spiritual well-being scale: Mental and physical health relationships. Oxford Textb Spiritual Healthe 2012;353-8.

Purborini N. Hubungan kesejahteraan spiritual lansia dengan penerimaan diri lansia di PSTW budi luhur. Skripsi. Yogyakarta: UGM; 2009.

Sugiyono (2016), Metode penelitian kuantitatif, kualitatif dan R\&D, PT Alfabet, Bandung.

Utama TA. Perbedaan kesejahteraan spiritual pasien sebelum dan sesudah operasi jantung di RSUP Dr Hasan Sadikin Bandung. J Keperawatan Unpad 2015. 